\title{
Peningkatan Hasil Belajar Pkn Melalui Model Pembelajaran Picture And Picture Berbantuan Flash Card Siswa Kelas 2 SD Negeri Kenteng 01
}

\author{
Senja Ayu Nurvita1, Slameto², Eunice Widyanti Setyaningtyas ${ }^{3}$ \\ 292013513@student.uksw.edu, slameto@staff.uksw.edu, eunice.widyanti@gmail.com \\ Pendidikan Guru Sekolah Dasar \\ Fakultas Keguruan dan IImu Pendidikan \\ Universitas Kristen Satya Wacana
}

\begin{abstract}
Based on the facts conducted by researchers at SDN Kenteng 01 this problem arises is the lack of interest in students to the learning process by teaching teachers that still use conventional methods. The purpose of this research is to apply the learning model of image and flash-assisted image and improve student learning outcomes with collaboration model. This research was conducted in grade 2 with type of research of PTK spiral model which was proposed by $\mathrm{C}$. Kemmis and Mc . Taggart In the study using 2 cycles of cycles I and II which consists of planning , step and reflection. Research data obtained from the test results and analyzed using descriptive techniques with the learning outcomes of Civics subjects on 2 cycles based on learning outcomes is $\geq 65$. The result of this research shows that there is an increase of learning result of Civics which can be seen on the value of learning result of Civics subject based on learning completeness that is cycle I is $66,77 \%$ and cycle II is $100 \%$. Based on these results, this study has succeeded in improving student learning outcomes of Civics subjects.
\end{abstract}

Keywords: Learning Outcomes, Picture and Picture, Flash Card, Civic Educations

\begin{abstract}
Abstrak
Berdasarkan hasil observasi yang dilakukan peneliti di SDN Kenteng 01 ini masalah yang timbul adalah kurangnya minat siswa untuk mengikuti proses belajar karena cara mengajar guru yang masih dengan metode konvesional sehingga minat siswa menurun untuk mengikuti proses pembelajaran. Penelitian ini dilakukan di kelas 2 dengan jenis penelitian PTK model spiral yang dikemukakan C. Kemmis dan Mc. Taggart. Dalam penelitian menggunakan 2 siklus yaitu siklus 1 dan 2 yang terdiri dari tahapan perencanaan, tindakan dan observasi, serta refleksi. Data penelitian diperoleh dari hasil tes dan dianalisa menggunakan teknik diskriptif komparatif dengan membandingkan hasil belajar mata pelajaran PKn pada 2 siklus berdasarkan ketuntasan hasil belajar yaitu $\geq 65$. Hasil penelitian menunjukkan adanya peningkatan hasil belajar PKn yang dapat terlihat pada nilai hasil belajar mata pelajaran PKn berdasarkan ketuntasan belajar yaitu siklus I sebesar $66,77 \%$ dan siklus II sebesar $100 \%$. Berdasarkan hasil perbandingan tersebut, penelitian ini telah berhasil meningkatkan hasil belajar siswa pada mata pelajaran PKn.
\end{abstract}

Kata Kunci: Hasil Belajar, Picture and Picture, Flash Card, Pendidikan Kewarganegaraan

\section{PENDAHULUAN}

Pendidikan sudah dimulai sejak manusia dilahirkan ke bumi. Pendidikan tersebut adalah pendidikan non-formal dan pendidikan formal. Pendidikan non-formal yang diajarkan orang tua di dalam 
keluarga. Sementara pendidikan formal yaitu melalui sekolah. Menurut (Undang-Undang Republik Indonesia, 2003), "pendidikan nasional berfungsi mengembangkan kemampuan dan membentuk watak serta peradaban bangsa yang bermartabat dalam rangka mencerdaskan kehidupan bangsa, bertujuan untuk mengembangkan potensi peserta didik agar menjadi manusia yang beriman dan bertakwa kepada Tuhan Yang Maha Esa, berakhlak mulia, sehat, berilmu, cakap, kreatif, mandiri, dan menjadi warga negara yang demokratis serta bertanggung jawab."

Perkembangan zaman sangat pesat, begitu juga dengan model pembelajaran. Pengembangan model pembelajaran terus dilakukan demi terciptanya pembelajaran yang sempurna memunculkan sebuah kurikulum baru yang diberi nama kurikulum 2013. Kurikulum 2013 ini adalah sebuah kurikulum yang tidak lagi berpusat pada disiplin ilmu atau mata pelajaran, tetapi menggabungkan beberapa mata pelajaran menjadi sebuah tema. Setelah adanya kurikulum yang lebih baik tersebut, dunia pendidikan terus mencari untuk menemukan terobosan-terobosan yang lain. Kurikulum 2013 ini memang dari awal dibagi menjadi tema dan bukan lagi menggunakan istilah mata pelajaran seperti kurikulum sebelumnya. Tema pada Kurikulum 2013 ini menggabungkan beberapa mata pelajaran. Hal ini relevan dengan pendapat Aprilia (2018: 62) yang mengatakan bahwa Kurikulum 2013 ini bersifat tematik integratif. Tematik integratif adalah pendekatan pembelajaran yang menggabungkan berbagai mata pelajaran ke suatu tema. Pengembangan model pembelajaran ini menjadi tantangan dan masalah baru untuk para tenaga pendidik yang harus berfikir kritis dan kreatif untuk memperbarui cara atau metode mengajar mereka.

Berdasarkan hasil observasi di SDN Kenteng 01, masalah-masalah yang timbul pada proses pembelajaran tersebut ditandai dengan gejala berkurangnya minat siswa untuk mengikuti pembelajaran ketika guru menyampaikan materinya siswa hanya asyik bermain, bercerita dengan teman, dan melakukan aktivitas lain diluar pembelajaran yang mengakibatkan turunnya hasil belajar siswa dan sebagian besar siswanya mendapatkan nilai dibawah KKM (Kriteria Ketuntasan Minimal). KKM yang diterapkan pada pelajaran PKn adalah 65. Dari 27 siswa yang mencapai ketuntasan hanya 11 orang siswa saja ( mendapatkan nilai 65 keatas) dan sebanyak 16 siswa belum mencapai ketuntasan.

Dari uraian masalah yang berdampak pada perubahan perilaku siswa yaitu siswa merasa bosan, enggan membaca uraian yang panjang, ketika guru menyampaikan materinya siswa hanya asyik bermain, bercerita dengan teman, dan melakukan aktivitas lain diluar pembelajaran dan data yang menunjukkan bahwa 11 siswa mencapai ketuntasan dan 16 siswa belum mencapai ketuntasan, maka disimpulkan adanya kekeliruan yang tanpa disadari oleh guru perlu dilakukannya pembenahan atau perbaikan pada proses pembelajaran tersebut. Guru harus bisa menerapkan cara pembelajaran yang menuntut siswa untuk lebih aktif menanggapi. Salah satu caranya adalah merubah proses pembelajaran menjadi lebih inovatif dan menyenangkan yaitu dengan menggunakan media yang bervariatif untuk menarik minat siswa mengikuti proses pembelajaran.

Model pembelajaran kooperatif Picture and Picture adalah salah satu alternatif model pembelajaran yang sering dikembangkan supaya menjadi model pembelajaran yang menciptakan suasana baru dan menyenangkan bagi siswa. Model pembelajaran tipe Picture and Picture ini dalam proses pembelajarannya menggunakan media gambar. Model ini sering dikolaborasikan dengan mediamedia pembelajaran yang bermacam-macam sehingga menjadi suatu model pembelajaran yang dapat membantu mencapai tujuan dari proses pembelajaran. Model Picture and Picture ini menjadi salah satu model yang dapat digunakan untuk mengatasi masalah-masalah dalam pembelajaran yang terjadi di SD Negeri Kenteng 01. Model ini akan dikolaborasikan oleh peneliti dengan media pembelajaran yang bernama Flash Card. Media ini berbentuk kartu bergambar yang dibaliknya akan ada keterangan dari gambar di sisi sebelumnya. Berdasarkan hasil observasi, belum ada guru yang mengunakan model pembelajaran ini.

Berdasarkan latar belakang tersebut dapat diidentifikasi masalah yang terkait sebagai berikut: 1) masih rendahnya hasil belajar PKn dengan bukti masih ada siswa yang nilainya dibawah KKM, 2) kreatifitas guru dalam memilih model dan metode pembelajaran yang masih kurang, 3) motivasi siswa 
yang rendah dalam pembelajaran PKn, 4) kemampuan siswa yang berbeda-beda dalam menyerap dan memahami materi pembelajaran dan penulis merumuskan masalah sebagai berikut, "Bagaimana penerapan proses model pembelajaran menggunakan Picture and Picture berbantuan Flash Card untuk meningkatkan hasil belajar PKn oleh siswa kelas II Sekolah Dasar Negeri Kenteng 01 Semester 2 Tahun Ajaran 2017/2018?, "Apakah penggunaan model pembelajaran Picture and Picture berbantuan media Flash Card dapat meningkatkan hasil belajar siswa kelas II Sekolah Dasar Negeri Kenteng 01 Semester 2 Tahun Ajaran 2017/2018."

Setelah mengidentifikasi masalah terkait, peneliti menentukan tujuan dari penelitian ini yaitu, menerapkan model pembelajaran Picture and Picture berbantuan Flash Card pada siswa kelas II Sekolah Dasar Negeri Kenteng 01 Semester 2 Tahun Ajaran 2017/2018 dan meningkatkan hasil belajar siswa kelas II menggunakan model pembelajaran Picture and Picture berbantuan media Flash Card Sekolah Dasar Negeri Kenteng 01 Semester 2 Tahun Ajaran 2017/2018.

Teori belajar menurut Gagne dalam Sapriati (2011:1.47), "belajar merupakan suatu proses yang memungkinkan seorang untuk mengubah tingkah lakunya cukup cepat, dan perubahan tersebut bersifat relatif tetap, sehingga perubahan yang serupa tidak perlu terjadi berulangkali setiap menghadapi situasi yang baru. Sudjana (2005 : 34) menyebutkan bahwa "Hasil belajar siswa pada hakikatnya adalah perubahan mencakup bidang kognitif, afektif, dan psikomotor yang berorientasi pada proses belajar mengajar yang dialami siswa."

Sementara itu, Meyer, W. J. (dalam Trianto, 2009: 21), secara kaffah "model dimaknakan sebagai suatu objek atau konsep yang digunakan untuk merepresentasikan sesuatu hal. Sesuatu yang nyata dan dikonversi untuk sebuah bentuk yang lebih komprehensif." Sebagai contohnya adalah sebuah ide yang nantinya akan menjadi sebuah karya. Sedangkan yang dimaksud dengan model pembelajaran menurut Joyce (dalam Trianto, 2009: 22) adalah "suatu perencanaan atau suatu pola yang digunakan sebagai pedoman dalam merencanakan pembelajaran di kelasatau pembelajaran dalam tutorial dan untuk menentukan perangkat-perangkat pembelajaran termasuk di dalamnya bukubuku, film, komputer, kurikulum, dan lain-lain."

Ibrahim (2000: 29) meyatakan bahwa model pembelajaran kooperatif picture and picture merupakan suatu model pembelajaran yang mengutamakan adanya kelompok-kelompok, yang secara sadar dan sistematis mengembangkan interaksi yang saling asah, saling asih, dan saling asuh. Pembelajaran kooperatif picture and picture bernaung dalam teori konstruktivis. Pembelajaran ini muncul dari konsep bahwa siswa akan lebih mudah menemukan dan memahami konsep yang sulit jika mereka saling berdiskusi dengan temannya. Siswa secara rutin bekerja dalam kelompok untuk saling membantu memecahkan masalah-masalah yang kompleks. Sementara itu, menurut Taniredja (2013: 55) pembelajaran kooperatif picture and picture merupakan sistem pengajaran yang memberi kesempatan pada anak didik untuk bekerja sama dengan sesama siswa dalam tugas-tugas yang berstruktur, berkelompok, sehingga terjadinya interaksi secara terbuka dan hubungan yang bersifat interdependensi efektif di antara anggota kelompok.

Sintaks dari model pembelajaran Picture and Picture adalah sebagai berikut: pertama, menyampaikan tujuan kompetensi yang ingin dicapai dan memberikan materi pengantar sebelum kegiatan. Kedua menyediakan gambar-gambar yang akan digunakan (berkaitan dengan materi). Ketiga, menunjukan siswa secara bergantian untuk mengurutkan gambar-gambar yang ada. Keempat, memberikan pertanyaan mengenai alasan siswa dalam menentukan urutan gambar. Kelima, menanamkan konsep atau materi sesuai dengan kompetensi yang ingin dicapai. Dan terakhir, siswa diajak untuk menyimpulkan/merangkum materi yang baru saja diterimanya. Model pembelajaran Picture and Picture memiliki beberapa kelebihan, yaitu: (1) materi yang diajarkan lebih terarah karena pada awal pembelajaran guru menjelaskan kompetensi yang harus dicapai dan materi secara singkat terlebih dahulu, (2) siswa lebih cepat menangkap materi ajar karena guru menunjukkan gambar-gambar mengenai materi yang dipelajari, (3) dapat meningkat daya nalar atau daya pikir siswa karena siswa disuruh guru untuk menganalisa gambar yang ada, (4) dapat meningkatkan tanggung jawab siswa, 
sebab guru menanyakan alasan siswa mengurutkan gambar, dan (5) pembelajaran lebih berkesan, sebab siswa dapat mengamati langsung gambar yang telah dipersiapkan oleh guru.

Pada pembelajaran kooperatif seperti Picture and Picture ini memperlukan adanya media pembelajaran yang bertujuan sebagai alat untuk merangsang pemikiran siswa dalam pembelajaran (Permana, 2015). Media yang digunakan dalam metode Picture and Picture ini adalah media Flash Card. Menurut Rudi Susilana dan Cepiriyana (2008: 95), Flash Card merupakan media pembelajaran yang berupa kartu bergambar berukuran 25 × $30 \mathrm{~cm}$. Gambar-gambar pada Flash Card merupakan serangkaian pesan yang disajikan dengan adanya keterangan pada setiap gambar. Dengan model Picture and Picture berbantuan media Flash Card ini dapat disimpulkan bahwa pembelajaran yang menekankan pada keaktifan siswa dalam melakukan kegiatan.

Berdasarkan kajian teori yang telah dipaparkan, dapat disimpulkan bahwa penerapan model Picture and Picture berbantuan media Flash Card pada mata pelajaran PKn dapat diterapkan dan meningkatkan hasil belajar siswa. Dengan harapan jika menggunakan metode Picture and Picture berbantuan media Flash Card diharapkan siswa akan mampu meningkatkan hasil belajar yang semula rendah akan menjadi tinggi dan siswa lebih bisa berfikir aktif, kritis, kreatif dan juga sadar akan pentingnya tujuan pembelajaran yang akan dicapai, bukan hanya sadar namun juga harus termotivasi dalam mengikuti pembelajaran di kelas.

Beberapa kajian praktis pernah dilakukan oleh beberapa peneliti sebelumnya, seperti Mawardi \& Desty Lusia Sari (2015), Ida Nurdiana (2012), Ida Reni Susanti (2012) menunjukkan bahwa model pembelajaran Picture and Picture meningkatkan hasil belajar yang signifikan. Inovasi yang penulis dalam melakukan penelitian dengan menggunakan model Picture and Picture berbantuan media Flash Card adalah meningkatkan kreativitas siswa serta prestasi siswa dalam kegiatan belajar mengajar, karena dalam penggunaan model Picture and Picture, siswa dituntut untuk aktif dan kreatif dalam setiap proses pembelajarannya. Seperti pendapat Handayani (2013: 326) yang menyatakan penggunaan model pembelajaran Picture and Picture ini dapat meningkatkan sikap ilmiah siswa. Langkah pembelajaran menggunakan model pembelajaran Picture and Picture ini terbagi menjadi tujuh tahapan yang telah dikolaborasikan dengan media Flash Card, pada awal kegiatan akan dilakukan apersepsi yang akan dikaitkan dengan penyampaian tujuan dan memperkenalkan materi pengantar sebelum kegiatan. Langkah selanjutnya guru akan menyediakan gambar-gambar yang akan digunakan (berkaitan dengan materi). Kemudian menunjukan siswa secara bergantian untuk mengurutkan gambar-gambar yang ada dan menanyakan alasan siswa dalam menentukan urutan gambar. Dari urutan gambar tersebut, guru mulai menanamkan konsep atau materi, dan memperkenalkan Flash Card sebagai alat bantu mereka sesuai dengan kompetensi yang ingin dicapai. Pada akhir kegiatan, siswa diajak untuk menyimpulkan/merangkum materi yang baru saja diterimanya dan mengerjakan soal evaluasi.

\section{METODE PENELITIAN}

Penelitian ini adalah penelitian tindakan kelas (PTK). Model penelitian menggunakan model spiral dari C. Kemmis dan Mc. Taggart. Konsep pokok penelitian tindakan menurut C. Kemmis dan Mc. Taggart dalam Arikunto terdapat empat tahap rencana tindakan pada tiap siklus, yaitu perencanaan, pelaksanaan, pengamatan, dan refleksi.

Pada penelitian, peneliti akan bertindak sebagai guru yang akan mengajar siswa dengan materi yang sudah terlampir pada RPP. Kemudian yang akan bertindak sebagai observer adalah guru kelas 2 . Dalam kajian ini, guru kelas akan mengisi lembar observasi sebagai tolak ukur keberhasilan guru (peneliti) dalam menyampaikan materi kepada siswa. Peneliti juga telah merencanakan membagikan konsep kolaborasi model dan media pembelajaran yang telah disusun untuk mengatasi siswa berkebutuhan khusus yang ada di kelas yaitu siswa ADHD dan Slow Learner.

Data yang diperoleh akan diolah secara kuantitatif dan kualitatif. Indikator keberhasilan yang digunakan adalah Kriteria Ketuntasan Minimal (KKM) sebesar 65, dengan setiap pertemuan per siklus 2 
jam pelajaran $(2 \times 35$ menit). Hasil belajar PKn meningkat apabila di atas $80 \%$ siswa memperoleh nilai di atas KKM. Data yang diperoleh berdasarkan hasil observasi guru dan siswa berupa penjelasan atau keterangan yang berupa data kualitatif yaitu diukur dengan kerja kelompok dan presentasi siswa, sedangkan data yang diperoleh berdasarkan hasil tes berbentuk angka-angka berupa data kuantitatif yang diukur dengan soal post test.

Data kualitatif dan kuantitatif dianalisis dengan menggunakan analisis deskriptif komparatif dengan cara membandingkan kondisi siklusi I dan siklus II guna mengetahui peningkatan hasil belajar PKn. Subjek penelitian ini adalah siswa kelas 2 SD Negeri Kenteng 01 Kecamatan Sempor Kabupaten Kebumen Semester II Tahun Pelajaran 2017/2018. Jumlah siswa kelas 2 adalah 27 siswa, terdiri dari 19 siswa laki-laki dan 8 siswa perempuan. Instrumen yang digunakan sudah teruji, yaitu soal posttest yang terdiri dari 20 soal pilihan ganda. Selain soal tes, penilaian juga dilakukan dengan lembar observasi (guru) dan lembar penilaian (siswa). Lembar observasi dan lembar penilaian ini digunakan memudahkan peneliti untuk mengamati perubahan/peningkatan hasil belajar siswa selain dari soal posttest. Berikut merupakan tabel hasil uji instrumen siklus I dan siklus II.

Tabel 1. Uji Validitas Soal Siklus I

\begin{tabular}{ccc}
\hline Jumlah Butir Soal & Valid & Tidak Valid \\
\hline 30 & 24 & 6 \\
\hline
\end{tabular}

Berdasarkan Tabel 1 terdapat 30 butir soal dengan nilai valid sebanyak 24 soal dan tidak valid sebanyak 6 soal.

Tabel 2. Uji Validitas Soal Siklus 2

\begin{tabular}{ccc}
\hline Jumlah Butir Soal & Valid & Tidak Valid \\
\hline 30 & 26 & 4 \\
\hline
\end{tabular}

Berdasarkan Tabel 1 terdapat 30 butir soal dengan nilai valid sebanyak 26 soal dan tidak valid sebanyak 4 soal.

Tabel 3. Soal Siklus 1 Reliability Statistics

\begin{tabular}{|r|r|r|}
\hline & $\begin{array}{c}\text { Cronbach's } \\
\text { Alpha Based } \\
\text { on } \\
\begin{array}{c}\text { Cronbach's } \\
\text { Alpha }\end{array}\end{array}$ & \\
\hline $\begin{array}{c}\text { Standardized } \\
\text { Items }\end{array}$ & N of Items \\
\hline, 929 &, 930 & 30 \\
\hline
\end{tabular}

Tabel 4. Soal Siklus 2 Reliability Statistics

\begin{tabular}{|c|c|c|}
\hline $\begin{array}{c}\text { Cronbach's } \\
\text { Alpha }\end{array}$ & $\begin{array}{c}\text { Cronbach's } \\
\text { Alpha Based } \\
\text { on } \\
\text { Standardized } \\
\text { Items }\end{array}$ & $\mathrm{N}$ of Items \\
\hline, 949 & ,947 & 30 \\
\hline
\end{tabular}

Berdasarkan hasil uji coba yang dilakukan oleh peneliti pada siklus I dilakukan dengan SPSS versi 20.0. Koefisien reliabilitas dapat dilihat melalui besarnya nilai Cronbach's Alpha yang disesuaiakan dengan klasifikasi koefisien yang sudah diungkapkan. Pada siklus I soal pilihan ganda nilai Cronbach's Alpha mencapai 0,929 berarti memiliki tingkat interpretasi yang tinggi reliabel. Sementara pada siklus II 
soal pilihan ganda nilai Cronbach's Alpha mencapai 0,949 berarti memiliki tingkat interpretasi yang tinggi.

\section{HASIL PENELITIAN}

Penulis menguraikan analisis hasil belajar dari semua siklus yang diterapkan pada penelitian ini. Pada siklus I, hasil belajar siswa telah meningkat daripada hasil belajar dari pra siklus. Hal ini dibuktikan dengan 18 siswa $(66,67 \%)$ yang mengalami ketuntasan dan 9 siswa $(3,33 \%)$ lainnya belum mengalami ketuntasan. Rata-rata nilai pada siklus ini naik menjadi 70,37 . Berikut hasil belajar siswa pada siklus I yang disajikan dengan tabel 1 .

Tabel 5. Evaluasi Hasil Belajar PKn Ranah Kognitif Siklus I Siswa Kelas 2 SD Negeri Kenteng 01

\begin{tabular}{lcc}
\hline & Jumlah Siswa & Persentase \\
\hline Jumlah keseluruhan siswa & 27 & $100 \%$ \\
Siswa yang tuntas & 18 & $66,67 \%$ \\
Siswa yang tidak tuntas & 9 & $33,33 \%$ \\
Jumlah & \multicolumn{2}{c}{$100 \%$} \\
Rata-rata & \multicolumn{2}{c}{$\mathbf{7 0 , 3 7}$} \\
Nilai tertinggi & \multicolumn{2}{c}{$\mathbf{9 0}$} \\
Nilai terendah & $\mathbf{5 0}$ \\
\hline
\end{tabular}

Tabel 6. Evaluasi Hasil Belajar PKn Ranah Afektif Siklus I Siswa Kelas 2 SD Negeri Kenteng 01

\begin{tabular}{lcc} 
& Jumlah Siswa & Persentase \\
\hline Jumlah keseluruhan siswa & 27 & $100 \%$ \\
Rata-rata & 83 & $70 \%$ \\
\hline
\end{tabular}

Tabel 7. Evaluasi Hasil Belajar PKn Ranah Psikomotor Siklus I

Siswa Kelas 2 SD Negeri Kenteng 01

\begin{tabular}{lcc}
\hline & Jumlah Siswa & Persentase \\
\hline Jumlah keseluruhan siswa & 27 & $100 \%$ \\
Rata-rata & 70 & $\mathbf{5 8 \%}$ \\
\hline
\end{tabular}

Berdasarkan tabel di atas menunjukkan bahwa perolehan hasil belajar PKn pada ranah kognitif melalui kolaborasi model pembelajaran Picture and Picture berbantuan Flash Card pada siklus I diperoleh data untuk nilai tertinggi yang diperoleh responden adalah 90 , nilai terendah adalah 50 . Sebanyak 18 siswa $(66,67 \%)$ mengalami ketuntasan dan sebanyak 9 siswa (33,33\%) mengalami ketidaktuntasan. Perolehan hasil belajar PKn pada ranah afektif diperoleh rata-rata 83 dengan persentase $70 \%$. Dan perolehan hasil belajar pada ranah afektif diperoleh rata-rata 70 dengan persentase $58 \%$.

Pada pelaksanaan siklus II, terjadi perubahan yang sangat signifikan. Hasil belajar siswa Pada siklus sebelumnya sebanyak 18 siswa $(66,67 \%)$ mengalami ketuntasan, sementara pada siklus II semua siswa kelas 2 yang berjumlah 27 orang $(100 \%)$ mencapai nilai tuntas dengan rata-rata nilai siswa 83,33. Berikut uraian hasil belajar PKn siswa pada siklus II yang disajikan dalam tabel.

Tabel 8. Evaluasi Hasil Belajar PKn Ranah Kognitif Siklus II Siswa Kelas 2 SD Negeri Kenteng 01

\begin{tabular}{lcc}
\hline & Jumlah Siswa & Persentase \\
\hline Jumlah keseluruhan siswa & 27 & $100 \%$ \\
Siswa yang tuntas & 27 & $100 \%$ \\
Siswa yang tidak tuntas & 0 & $100 \%$ \\
\hline
\end{tabular}


Senja Ayu Nurvita ${ }^{1}$, Slameto², Dkk

\begin{tabular}{lc}
\hline Jumlah & $100 \%$ \\
Rata-rata & 83,33 \\
Nilai tertinggi & 100 \\
Nilai terendah & 70 \\
\hline
\end{tabular}

Tabel 9. Evaluasi Hasil Belajar PKn Ranah Afektif Siklus II Siswa Kelas 2 SD Negeri Kenteng 01

\begin{tabular}{lcc}
\hline & Jumlah Siswa & Persentase \\
\hline Jumlah keseluruhan siswa & 27 & $100 \%$ \\
Rata-rata & 95 & $100 \%$ \\
\hline
\end{tabular}

Tabel 10 Evaluasi Hasil Belajar PKn Ranah Psikomotor Siklus II Siswa Kelas 2 SD Negeri Kenteng 01

\begin{tabular}{ccc}
\hline & Jumlah Siswa & Persentase \\
\hline Jumlah keseluruhan siswa & 27 & $100 \%$ \\
Rata-rata & 80 & $100 \%$ \\
\hline
\end{tabular}

Tabel diatas menunjukkan perolehan hasil belajar PKn pada ranah kognitif melalui kolaborasi model pembelajaran Picture and Picture berbantuan Flash Card pada siklus II diperoleh data untuk nilai tertinggi yang diperoleh responden adalah 90 , nilai terendah adalah 50 . Sebanyak 18 siswa $(66,67 \%)$ mengalami ketuntasan dan sebanyak 9 siswa $(33,33 \%)$ mengalami ketidaktuntasan. Perolehan hasil belajar PKn pada ranah afektif diperoleh data, rata-rata 95 dengan persentase 100\%. Dan perolehan hasil belajar pada ranah afektif diperoleh rata-rata 80 dengan persentase $100 \%$.

\begin{tabular}{cccc}
\hline \multirow{2}{*}{ Kriteria } & \multicolumn{2}{c}{ Hasil Belajar PKn } & \multirow{2}{*}{ Keterangan } \\
& Siklus I & Siklus II & \\
\hline Rata- Rata & 83 & 95 & meningkat \\
Persentase & $70 \%$ & $100 \%$ & meningkat \\
\hline
\end{tabular}

Hasil belajar secara keseluruhan menunjukkan peningkatan pada setiap siklus, baik pra siklus, siklus I, dan siklus II. Peningkatan ini dapat terjadi karena adanya kolaborasi model pembelajaran Picture and Picture yang dibantu dengan media Flash Card membuat siswa tertarik dan mau untuk belajar karena menggunakan alat peraga yang menyenangkan. Berikut adalah tabel hasil belajar dan tabel perbandingan pada pra siklus, siklus I, dan siklus II.

Tabel 11. Perbandingan Hasil Belajar Ranah Kognitif Pra Siklus, Siklus I, dan Siklus II

\begin{tabular}{ccccc}
\hline Indikator Hasil & \multicolumn{4}{c}{ Hasil Belajar Siswa } \\
Belajar & Pra Siklus & Siklus I & Siklus II & \multirow{2}{*}{ Keterangan } \\
\hline Rata - Rata & 61,30 & 70,37 & 83,33 & Meningkat \\
Siswa yang tuntas & 11 & 18 & 27 & Meningkat \\
\hline
\end{tabular}

Tabel 12. Perbandingan Hasil Belajar PKn Ranah Afektif Siklus I dan Siklus II

\begin{tabular}{cccc}
\hline \multirow{2}{*}{ Kriteria } & \multicolumn{2}{c}{ Hasil Belajar PKn } & \multirow{2}{*}{ Keterangan } \\
& Siklus I & Siklus II & \\
\hline Rata- Rata & 83 & 95 & meningkat \\
Persentase & $70 \%$ & $100 \%$ & meningkat \\
\hline
\end{tabular}


Tabel 13. Perbandingan Hasil Belajar PKn Ranah Psikomotor Siklus I dan Siklus II

\begin{tabular}{cccc}
\hline \multirow{2}{*}{ Kriteria } & \multicolumn{2}{c}{ Hasil Belajar PKn } & \multirow{2}{*}{ Keterangan } \\
& Siklus I & Siklus II & \\
\hline Rata- Rata & 70 & 80 & meningkat \\
Persentase & $58 \%$ & $100 \%$ & meningkat \\
\hline
\end{tabular}

Data yang diperoleh dari beberapa tabel diatas menunjukkan bahwa terjadi peningkatan hasil belajar PKn tidak hanya dari ranah kognitif saja tetapi juga pada ranah afektif dan psikomotor. Dari hasil analisa diperoleh bahwa ranah yang paling tinggi pada siklus I adalah afektif dan terendah adalah ranah psikomotor. Sementara itu pada siklus II semua ranah baik kognitif, afektif dan psikomotor mencapai $100 \%$. Berikut adalah perbandingan aspek ranah kognitif, afektif, dan psikomotor antara siklus I dan siklus II.

Tabel 14. Perbandingan Nilai Ranah Afektif, Kognitif, dan Psikomotor pada siklus I dengan siklus II

\begin{tabular}{lcccccc}
\hline Kriteria & \multicolumn{3}{c}{ Siklus I } & \multicolumn{3}{c}{ Siklus II } \\
& Kognitif & Afektif & $\begin{array}{c}\text { Psiko } \\
\text { motor }\end{array}$ & Kognitif & Afektif & $\begin{array}{c}\text { Psikom } \\
\text { otor }\end{array}$ \\
\hline Rata-Rata & 70,37 & 83 & 70 & 83,33 & 95 & 80 \\
Persentase & $66,67 \%$ & $70 \%$ & $58 \%$ & $100 \%$ & $100 \%$ & $100 \%$ \\
\hline
\end{tabular}

Data yang diperoleh dari hasil tes kognitif dianalisis menggunakan analisis komparatif. Hasil dari analisis tersebut adalah yang tertulis pada bawah dibawah ini.

Tabel 15. Analisis Komparatif Ketuntasan Hasil Belajar PKn Ranah Kognitif Siswa Kelas 2 SD Negeri Kenteng 01

\begin{tabular}{cccccccc}
\hline \multirow{2}{*}{ No } & Ketuntasan & \multicolumn{2}{c}{ Pra Siklus } & \multicolumn{2}{c}{ Siklus I } & \multicolumn{2}{c}{ Siklus II } \\
& Belajar & $\mathrm{f}$ & $\%$ & $\mathrm{f}$ & $\%$ & $\mathrm{f}$ & $\%$ \\
\hline 1 & Tuntas & 11 & $40,74 \%$ & 18 & $66,67 \%$ & 27 & $100 \%$ \\
2 & Tidak Tuntas & 16 & $59,26 \%$ & 9 & $33,33 \%$ & 0 & $0 \%$ \\
& Rata-rata & \multicolumn{2}{c}{61,30} & & 70,37 & \multicolumn{2}{c}{83,33} \\
Nilai Tertinggi & \multicolumn{2}{c}{85} & \multicolumn{2}{c}{90} & \multicolumn{2}{c}{100} \\
Nilai Terendah & 40 & & 50 & 70 \\
\hline
\end{tabular}

Dari hasil pembahasan secara keseluruhan, rancangan penelitian yang dilakukan oleh peneliti untuk menerapkan model pembelajaran Picture and Picture berbantuan Flash Card telah berhasil dilakukan. Tahap demi tahap sudah dilakukan dengan baik sehingga minat dan motivasi siswa semakin kuat dan siswa semakin aktif untuk mengikuti proses pembelajaran. Selain itu, model ini dikatakan berhasil untuk meningkatkan hasil belajar siswa. Hal ini dapat dilihat dari hasil belajar siswa dari semua ranah baik kognitif, afektif, dan psikomotor yang pada setiap siklusnya mengalami peningkatan yang baik.

\section{HASIL DAN PEMBAHASAN}

Penulis memaparkan semua siklus yang diterapkan pada penelitian ini. Pada tahap awal, peneliti melakukan observasi dan mendapatkan hasil belajar siswa sebelum dilakukannya tindakan (pra siklus). Dari hasil observasi, diketahui bahwa metode yang diterapkan guru masih sangat sederhana yaitu dengan metode konvensional. Hal ini membuat suasana belajar menjadi membosankan. Hal ini relevan 
dengan hasil penelitian yang dilakukan Alfiah (2017: 4) yang menyatakan bahwa guru dalam pembelajaran kurang inovatif sehingga siswa kurang aktif dan guru belum menggunakan multimedia.

Pada tahapan selanjutnya, peneliti melanjutkan ke siklus I. Dalam siklus ini, perubahan proses belajar mengajar sudah mulai terlihat. Beberapa siswa sudah mulai fokus dan antusias dengan proses pembelajaran ini, dan mereka juga sudah mulai berani menjawab pertanyaan dari guru tersebut walaupun hanya sejumlah orang saja. Selama pembelajaran berlangsung pada pertemuan pertama dan kedua, dengan penerapan model pembelajaran Picture and Picture berbantuan Flash Card berjalan dengan baik namun masih terdapat beberapa permasalahan dalam pembelajaran diantaranya siswa yang tidak memperhatikan guru, masih cenderung mencari kesibukan sendiri bahkan hingga berjalanjalan di dalam kelas dan berbicara dengan teman yang lain, beberapa siswa masih tidak fokus dalam mengikuti pelajaran dan terlihat masih pasif dalam kegiatan pembelajaran yaitu dalam proses pembelajaran mereka hanya diam dan terkadang melamun, tidak merespon dengan baik apa yang ditanyakan oleh guru dan ada juga beberapa slow learner dalam menerima materi. Ketika guru menyampaikan tujuan pembelajaran dan memberikan materi pengantar sebelum kegiatan, beberapa siswa sudah memperhatikan dengan baik. Kemudian, pada saat guru menyediakan gambar-gambar dan menunjuk siswa secara bergantian untuk mengurutkan gambar-gambar yang ada, minat dan antusias siswa menunjukkan peningkatan dibandingkan dengan pra siklus. Pada langkah pembelajaran selanjutnya, ketika guru memberikan pertanyaan mengenai alasan siswa dalam menentukan urutan gambar dan menanamkan konsep atau materi sesuai dengan kompetensi yang ingin dicapai, siswa duduk dengan rapi dan baik. Dan ketika guru mengajak siswa untuk menyimpulkan atau merangkum materi yang baru saja diterimanya, beberapa siswa sudah menjawab dan menyimpulkan. Namun, karena hasil yang dicapai oleh siswa belum sesuai dengan yang diharapkan dan belum mencapai indikator kinerja yang ditetapkan, maka peneliti merencanakan kegiatan pembelajaran selanjutnya di siklus II dengan memperbaiki kekurangan dan kesalahan yang terjadi pada siklus I.

Pada siklus II, pelaksanaan penelitian tindakan kelas dengan menggunakan model pembelajaran Picture and Picture berbantuan Flash Card sudah meningkat secara keseluruhan karena dalam proses pembelajaran guru mampu memperbaiki pembelajaran dengan mengatasi permasalahan yang terjadi pada siklus sebelumnya. Pada siklus ini guru telah berhasil membuat siswa fokus dalam pembelajaran dibuktikan dengan siswa mampu menyelesaikan tugas yang diberikan guru dan mampu menyimpulkan hasil pembelajaran yang baru saja mereka lakukan. Ketika guru menyampaikan tujuan pembelajaran dan memberikan materi pengantar sebelum kegiatan, beberapa siswa sudah memperhatikan dengan sangat baik dan tenang. Pada saat guru menyediakan gambar-gambar dan menunjuk siswa secara bergantian untuk mengurutkan gambar-gambar tersebut, minat dan antusias siswa menunjukkan peningkatan yang baik pada siklus II ini. Pada langkah pembelajaran selanjutnya, saat guru memberikan pertanyaan mengenai alasan siswa dalam menentukan urutan gambar dan menanamkan konsep atau materi sesuai dengan kompetensi yang ingin dicapai, siswa duduk dengan sangat rapi dan baik. Dan ketika guru mengajak siswa untuk menyimpulkan atau merangkum materi yang baru saja diterimanya, beberapa siswa sudah menjawab dan menyimpulkan.

Dengan demikian, siswa sudah benar-benar paham dengan materi yang mereka pelajari. Dan sebelum menutup pertemuan, guru selalu menanyakan kepada siswa tentang materi yang belum mereka pahami sehingga seluruh siswa benar-benar mengerti tentang materi yang dipelajari. Dengan mengatasi masalah dan memperbaiki proses pembelajaran pada siklus sebelumnya, model Picture and Picture berbantuan Flash Card ini terbukti membuat hasil belajar siswa meningkat pada siklus ini dibandingkan dengan siklus sebelumnya.

Secara keseluruhan, penelitian dengan menggunakan model pembelajaran Picture and Picture berbantuan Flash Card ini, telah menunjukkan bahwa adanya peningkatan hasil belajar yang sangat signifikan. Komunikasi dan interaksi antara guru dan siswa berjalan dengan baik. Manajemen waktu mengajar baik dan tepat waktu dan semakin baik pada setiap siklus. Namun, tidak hanya hasil belajarnya saja yang meningkat, dari sikap siswa dalam merespon dan mengikuti proses pembelajaran 
pun sudah mengalami peningkatan yang cukup baik. Setelah dilaksanakan pembelajaran menggunakan Picture and Picture berbantuan Flash Card pada siklus I dan siklus II ternyata dapat meningkatkan hasil belajar siswa karena model pembelajaran ini siswa yang dituntut aktif untuk mencari tahu, memiliki sikap disiplin dan bekerjasama sehingga semua siswa paham dengan materi yang dipelajari, sementara guru lebih pasif dan mengawasi saja. Hal ini sesuai dengan pendapat Astuti (2018: 104) yang menyatakan bahwa peran guru dalam pembelajaran hanya sebagai fasilitator yang artinya hanya sebagai informan, jadi siswa yang terlibat aktif dalam pembelajaran. Sehingga akan melatih siswa untuk aktif, melatih sisa kreatif dan inovatif, berani mengeluarkan pendapat, dan memiliki sikap tanggung jawab terhadap tugasnya. Model pembelajaran Picture and Picture ini akan lebih efektif apabila digunakan dalam mata pelajaran yang mempunyai banyak materi dan bacaan di dalam bukunya yang berdampak pada kebosanan siswa dalam mengikuti pembelajaran. Cara untuk mengatasi dampak ini adalah dengan menerapkan model atau media pembelajaran yang inovatif dan bisa membuat siswa kreatif dan tertarik untuk belajar salah satunya dengan model pembelajaran Picture and Picture yang berbantuan dengan Flash Card. Hal ini juga berdampak pada hasil belajar siswa karena siswa akan lebih memahami materi yang diajarkan oleh guru.

Berdasarkan hasil penelitian yang dijelaskan diatas, maka model pembelajaran Picture and Picture berbantuan media Flash Card memberikan pengaruh pada peningkatan kognitif siswa. Hal ini sesuai dengan teori kognitif Menurut Suprijono (2011: 16) bahwa belajar adalah proses mental yang aktif untuk mencapai, mengingat dan menggunakan pengetahuan menekankan belajar sebagai aktivitas yang melibatkan proses berfikir yang sangat kompleks dan teori kognitif menekankan belajar sebagai aktivitas yang melibatkan proses berpikir yang sangat kompleks.

Peningkatan hasil belajar dan perubahan sikap belajar yang dialami siswa merupakan kelebihan dari penerapan model pembelajaran Picture and Picture berbantuan media Flash Card. Selain mempunyai kelebihan, tentu juga model dan media ini mempunyai kekurangan dalam penerapannya. Kekurangan tersebut dialami pada proses pembelajaran karena masih adanya siswa yang masih cenderung mencari kesibukan sendiri, tidak memperhatikan saat guru sedang menyampaikan, bahkan hingga berjalan-jalan di dalam kelas dan berbicara dengan teman yang lain. Selain itu, beberapa siswa masih kurang konsentrasi dalam mengikuti pelajaran, siswa masih pasif dalam kegiatan pembelajaraan, ada siswa slow learner.

Namun, kekurangan tersebut dapat diatasi oleh guru pada kegiatan belajar pada tahap perbaikan dengan cara guru membimbing siswa untuk selalu fokus dalam pembelajaran karena dalam setiap akhir pembelajaran guru memberikan tugas kepada masing-masing siswa menyimpulkan hasil pembelajaran. Selanjutnya, untuk mengatasi siswa yang masih pasif dalam kegiatan pembelajaran guru selalu memberikan rangasangan berupa pertanyaan kepada siswa sehingga siswa dapat merespon rangsangan yang diberikan oleh guru sehingga siswa menjadi lebih aktif dalam pembelajaran. Untuk mengatasi slow learner, dalam memberikan materi guru memberikan perlakuan khusus yaitu lebih memperhatikan dan sering mengulang penjelasan materi yang belum mereka pahami kepada siswa tersebut serta memperkenalkan media yang digunakan dan menerapkan model pembelajaran sesuai dengan sintaks secara berulang ulang dan perlahan. Hal ini sependapat dengan Raharjo (2012: 40) yang menyatakan bahwa pemberian perlakuan khusus terhadap siswa-siswa yang mengalami slow learner mempunyai pengaruh terhadap kemapuan daya ingat siswa. Sementara itu untuk mengatasi anak ADHD dengan model pembelajaran ini adalah dengan cara membiasakan siswa tersebut dengan pertanyaan untuk membuat perhatiannya kembali kepada guru dan memintanya aktif dalam pembelajaran. Hal ini relevan dengan pendapat Kurniasari (2015: 7) yang menyebutkan bahwa memancing siswa ADHD untuk dengan memberikan pertanyaan secara langsung dapat dilakukan guru untuk mengetahui sejauh mana siswa mengetahui dan memahami materi yang sudah dijelaskan. Cara yang dilakukan peneliti ini telah berhasil untuk mengatasi siswa yang berkebutuhan khusus pada proses pembelajaran Picture and Picture berbantuan Flash Card. 
Pada penelitian ini peran media Flash Card juga sangat berpengaruh pada pembelajaran, karena Flash Card merupakan alat bantu dalam proses pembelajaran dengan media gambar yang disertai dengan kata-kata sebagai keterangannya. Hal ini sependapat dengan Setiawati (2015: 3) yang menyatakan media gambar dapat membantu siswa dalam mengenal bentuk benda yang asli melalui gambar dan melatih siswa agar dapat mengamati, menggambarkan dan menyimpulkan, sehingga pemahaman siswa terhadap materi pelajaran yang disampaikan dapat tercapai. Dengan menggunakan media Flash Card siswa lebih mudah dalam belajar karena berbentuk kartu kecil yang disertai dengan keterangan sehingga terlihat menarik perhatian dan mudah diingat isinya. Flash Card dapat menjadi media yang sesuai dengan langkah pembelajaran scientific yang saat ini sedang ingin diterapkan di Indonesia dan dianggap akan membuat efektif karena mampu mendorong siswa lebih mandiri dalam memahami materi. Maka dari itu, Flash Card ini dapat menjadi alternatif baru bagi siswa untuk lebih mudah untuk memahami sehingga siswa paham dengan materi baru yang disampaikan, hal itu berdampak pada hasil belajar siswa menjadi lebih baik.

\section{SIMPULAN}

Berdasarkan hasil penelitian, maka dapat disimpulkan bahwa cara penerapan model pembelajaran Picture and Picture dikolaborasikan dengan media pembelajaran Flash Card yang dilakukan oleh peneliti adalah dengan memperkenalkan model pembelajaran Picture and Picture pada awal pertemuan, dan menggunakan media gambar yang berukuran sedang hingga besar sehingga mudah untuk dipahami dan dipelajari siswa. Dan pada pertemuan selanjutnya guru memperkenalkan media kolaborasinya yaitu Flash Card. Kemudian pada akhir kegiatan sebelum posttest, guru menyelipkan sebuah permainan dengan bantuan model dan media pembelajaran yang telah dipelajari siswa dan telah terbukti adanya peningkatan hasil belajar PKn melalui model pembelajaran Picture and Picture berbantuan Flash Card pada siswa kelas 2 SD Negeri Kenteng 01 Kecamatan Sempor Kabupaten Kebumen tahun pelajaran 2017/2018.

Untuk kemajuan dalam pendidikan di masa sekarang, sebaiknya sekolah memberikan dan kesempatan bagi guru untuk melakukan inovasi dan mengembangkan kreatifitasnya dalam menjalankan proses belajar mengajar dengan menggunakan alat peraga dan dengan memberikan media menarik atau permainan dalam belajar. Selain itu, guru juga harus lebih kreatif dan inovatif untuk menerapkan proses pembelajaran yang dapat mengembangkan kemampuan siswa untuk berfikir kritis, aktif, dan mengembangkan kemampuan siswa untuk menyesuaikan dengan pengetahuan baru yang dimiliki siswa.

\section{DAFTAR RUJUKAN}

Alfiah. 2017. Peningkatan kualitas pembelajaran IPA melalui model kooperatif tipe Picture and Picture pada siswa kelas II SD Negeri 008 Tembilahan Hulu Kecamatan Tembilahan Hulu Semester I tahun pelajaran 2014/2015. Jurnal Widya Sari, 19(6), 21-32.

Aprilia, L. A., Setyaningtyas, E. W., \& Slameto. 2018. Meningkatkan Hasil Belajar IPA dengan Penerapan Model Pembelajaran Jigsaw Berbasis Kurikulum 2013. Wacana Akademia, 2(1), 6172.

Aqib, Z. 2015. Model-model Media, dan Strategi Pembelajaran Kontekstual (INOVATIF). Bandung: Penerbit YRAMA WIDYA.

Astuti, D. A. P., Slameto, \& Setyaningtyas, E. W. (2018). Pengaruh Model Pembelajaran Problem Based Learning Terhadap Kemampuan Pemecahan Masalah Matematika Siswa Sekolah Dasar. Jurnal Sekolah, 2(2), 102-109.

Dahar, Ratna Wilis. 2011. Teori-teori Belajar dan Pembelajaran. Jakarta: Erlangga

Fida Reni Susanti. 2012. Penggunaan Metode Picture and Picture Dengan Media Gambar Untuk Meningkatkan Hasil Belajar Siswa Pada Mata Pelajaran IPS Pokok Bahasan Perkembangan 
Teknologi Produksi, Komunikasi, dan Transportasi di Kelas IV SD Negeri Pojok Kecamatan Pulokulon Kabupaten Grobogan Semester II tahun 2011/2012. Skripsi. Salatiga: FKIP Universitas Kristen Satya Wacana.

Handayani, D., Bintari, H. S., \& Lisdiana. (2013). Penerapan Model Pembelajaran Picture and Picture berbantuan Spesimen pada Materi Invertebrata. Unnes Journal of Biology Education, 2(3), 322328.

Istarani, 58 Model Pembelajaran Inovatif (Referensi Guru Dalam Menentukan Model Pembelajaran). (Medan: Media Persada, 2011), hlm.1-8.

Kustandi, Cecep dan Bambang Sutjipto. 2011. Media Pembelajaran; Manual dan Digital. Bogor: Ghalia Indonesia.

Kurniasari, B. R. 2015. Layanan Guru Pada Siswa Attention Deficit Hyperactivity Disorder (ADHD) di kelas V SD N 1 Sedayu Kecamatan Sedayu Kabupaten Bantul. Jurnal Pendidikan Guru Sekolah Dasar, 6(4), 1-12.

Sari, Desty Lusia dan Mawardi. 2015. Keefektifan Model Pembelajaran Picture and Picture dan Make a Match Ditinjau dari Hasil Belajar Dalam Pembelajaran IPA Kelas 4 SD Gugus Mawar. (online), (http://www.repository.uksw.edu), diakses tanggal 20 Maret 2018.

Makmun Khairani. 2014. Psikologi Belajar. Yogyakarta: Aswaja Pressindo.

Nurdiana, Ida. 2012. Penerapan model pembelajaran Picture and Picture untuk meningkatkan aktivitas dan hasil belajar IPS kelas 3 di SDN Tumpang 02 Kecamatan Tumpang Kabupaten Malang. (online), (http://library.um.ac.id), diakses tanggal 20 Maret 2018.

Permana, E. P. (2015). PENERAPAN METODE PROBLEM SOLVING DENGAN MEDIA GAMBAR SERI UNTUK MENINGKATKAN HASIL BELAJAR IPS KELAS IV SEKOLAH DASAR. Jurnal Pendidikan Dasar Nusantara, 1(1), 1-16.

Raharjo, T. 2012. Peningkatan Kemampuan Daya Ingat Anak Slow Learner Melalui Terapi Kognitif Pada Anak Sekolah Dasar. , 5(1), 34-41.

Rayandra Asyar. 2012. Kreatif Mengembangkan Media Pembelajaran. Jakarta: Gaung Persada Press.

Rudi, S., \& Cepi, R. 2008. Media Pembelajaran. Bandung: Jurusan Kurtekpend FIP UPI.

Setiawati, N. L. M., Dantes, N., \& Candiasa, M. I. 2015. Pengaruh Penggunaan Media Gambar Flash Card Terhadap Minat dan Hasil Belajar IPA Peserta Didik Kelas VI SDLBB Negeri, Journal Program Pascasarjana Universitas Pendidikan Ganesha, 5(1), 3.

Sharan, Sholomo. 2009. Cooperative Learning Jogjakarta: Imperium.

Suprijono, A. 2011. Cooperative Learning: Teori dan Aplikasi PAIKEM. Yogyakarta: Pustaka Pelajar.

Undang-Undang Republik Indonesia. 2003. Undang-Undang Republik Indonesia Nomor 20 Tahun 2003 Tentang Sistem Pendidikan Nasional : Depdiknas 